\title{
OPTIMALISASI NILAI-NILAI KEAGAMAAN ANAK-ANAK DESA CAKRU MELALUI KEGIATAN BELAJAR MALAM
}

\author{
Hasan, M. Syihabuddin, Basuki Rahmat, Muhammad Rijali, Zamzami, \\ Abdurraman, Ubai dillah
}

Sekolah Tinggi Ilmu al-Qur'an (STIQ) Amuntai

\begin{abstract}
Abstrak
Pengoptimalan nilai-nilai keagamaan dapat dilaksanakan dengan cara apapun dan kapanpun, salah satunya dengan cara belajar malam. Belajar malam yang diadakan oleh mahasiswa KKN adalah sebuab kegiatan pembelajaran yang didalamnya bukan hanya tentang pembelajaran saja namun juga ada penanaman nilai-nila agama. Penelitian ini bertujuan untuk mendeskripsikan kegiatan belajar malam dalam mengoptimalisasikan nilai-nilai keagamaan anak-anak desa Cakru. Penelitian ini mengunakan metode deskriptif kualitatif dengan menjadikan Mahasiswa KKN didesa Cakeru sebagai subjek penelitian. Data dikumpulkan dengan teknik observasi, wawancara, dan dokumentasi yang kemudian dianalisis untuk mendaptkan kesimpulan. Hasil Penelitian menunjukan bahwa: Pelaksanaan kegiatan Belajar Malam didesa Cakru dilaksanakan dengan mekanisme yang telah ditentukan yaitu perencanaan, persiapan, dan pelaksanaan kegiatan. Pelaksanaan kegiatan ini mempunyai rentetan kegiatan yaitu Pemberian Motivasi, penambahan wawasan nilai keagamaan, pemberian nasehat, pembelajaran tahsin bacaan, mengaji bersama, mengajarkan ilmu agama, Pelatiban Adzan, Pelatihan Imam, Pelatihan Sholat berjamaah dan lain-lain
\end{abstract}

Kata Kunci: Optimalisasi, Nilai-nilai Keagamaan, Belajar Malam

\section{PENDAHULUAN}

Lingkungan memainkan peran penting dalam membentukan kepribadian anak. Anak yang tumbuk di lingkungan yang baik dan bagus maka ia akan menjadi kepribadian yang baik dan bagus dan sebaliknya apabila terbentuknya anak di lingkungan yang buruk maka akan menjadikan anak yang berkepribadian yang tidak baik. Ini menunjukkan bahwa pada dasarnya setiap anak mempunyai pembawaan yang berbeda dengan anak lainya karena pembawaan itu adalah cikal bakal dari sifat dan karakter yang yang di bawa setiap individu anak. Selain itu, pembawaan setiap anak juga hanya akan tumbuh dan berkembang sesuai dengan lingungan sosialnya mereka karena pada dasarnya manusianya merupakan makhluk sosial. Lingkungan yang kurang baik bagi anak akan menimbulkan kebiasaan-kebiasaan yang buruk bagi anak. 
Sedangkan lingkungan yang baik, latihan-latihan yang baik akan membantu memperbaiki perilaku anak menjadi pribadi yang baik.

Perkembangan arus globalisasi pada saat ini semakin cepat dan dampaknya tidak selalu positif. Kebanyakan dari anak-anak selalu kebablasan dengan teknologi yang ada pada sekarang ini. Berbagai macam kemajuan atau kecanggihan teknologi dan kecepatan informasi digital juga dapat menjadikan salah satu faktor yang bisa menghambat perkembanagan anak apabila orang tua tidak memperhatikan anak dengan baik. Kebanyakan dari mereka lebih suka dengan semartpon dan permainan geme sehingga mereka tidak mengenal waktu lagi apabila sudah bermain geme dan ini akan berdampak pada sekomotorik anak sehingga anak tersebut tidak mempunyai keahlian dalam berbagai bidang dan cenderong anak mempunyai sifat pemalas dan pemalu untuk menunjukkan bakatnya.

Jika dikaitkan dengan nilai-nilai agama islam, kondisi ini sangat memperhatikan dan jauh dari pada harapan. Tentu hal ini tidak seharus terjadi, problem tersebut merupakan salah satu bagian dari krisis multidimensional yang berpangkal dari krisis akhlak atau moral anak. oleh karena itu kita harus memberi pengetahuan dan pemahaman mengenai ajaran agama islam kepada anak sejak dini sebagai bekal dalam kehidupannya. Dengan bekal pengetahuan ajaran islam, maka seiring dengan bertambahnya usia anak, ia akan tahu bagaiamana harus bersikap terhadap tuhan, sesame, dan terhadap lingkungan sekitarnya. Anak akan bertindak sesuai dengan aturan nilai-nilai agama islam. Pengoptimalan nilai-nilai keagamaan dapat dilaksanakan dengan cara apapun dan kapanpun, salah satunya dengan cara belajar yang di adakan oleh mahasiswa KKN desa Cakru adalah sebuah kegiatan pembelajaran yang di dalamnya bukan hanya tentang pembelajaran saja namun juga ada penanaman nilainilai agama islam. selanjutnya, dalam tulisan ini penulis akan memfokuskan pada halhal mengoptimalkan nilai-nilai keagamaan ke pada anak-anak desa Cakru melalui kegiatan belajar malam yang dilakukan oleh mahasiswa KKN STIQ di desa Cakru.

\section{4}




\section{METODE PENELITIAN}

Penelitian dengan judul "Optimalisai Nilai-Nilai Keagamaan Anak-Anak Desa Cakeru Melalui Kegiatan Belajar Malam" merupakan pendekatan kualitatif. Pendekatan kualitatif sebagai prosedur penelitian yang menghasilkan data deskriptif berupa katakata tertulis atau lisan dari orang-orang atau perilaku yang dapat diamati. ${ }^{1}$

Penelitian ini merupakan penelitian yang bersifat penelitian deskriptif. Penelitian deskriptif adalah suatu bentuk penelitian yang paling dasar yang ditujukan untuk mendeskripsikan atau menggambarkan fenomena-fenomena yang ada, baik fenomena yang bersifat alamiah ataupun rekayasa manusia. ${ }^{2}$ Dengan demikian dapat diketahui bahwa tujuan utama dilakukannya penelitian deskriptif adalah menggambarkan secara sistematis fakta dan karakteristik subjek dan objek yang diteliti secara tepat. Penelitian ini bertujuan untuk mendeskripsikan suatu keadaan, melukiskan dan menggambarkan"Optimalisai Nilai-Nilai Keagamaan Anak-Anak Desa Cakru Melalui Kegiatan Belajar Malam" yang dituangkan dalam bentuk laporan dan uraian berupa kata-kata dan bukan angka-angka atau statistik.

Penelitian ini dilaksanakan di desa Cakru. Subjek dalam penelitian ini adalah mahasiswa KKN Sekolah Tinggi Ilmu Alquran Amuntai yang ber KKN di desa Cakru. Data dikumpulkan dengan teknik observasi, wawancara, dan dokumentasi yang kemudian di analisis untuk mendapatkan kesimpulan

${ }^{1}$ Lexy J. Moelong, Metodologi Penelitian Kualitatif (Bandung: PT. Remaja Rosdakarya, 2006), h. 4.

2 Nana Syaodih Sukmadinata, Metode Penelitian Pendidikan (Bandung: PT. Remaja Rosdakarya, 2010). 
Letak geografis desa Cakru adalah J1. Keramat, Desa Cakru, Kec. Amuntai Utara, Kab. Hulu Sungai Utara, Provinsi Kalimantan Selatan, Kode pos 71471.

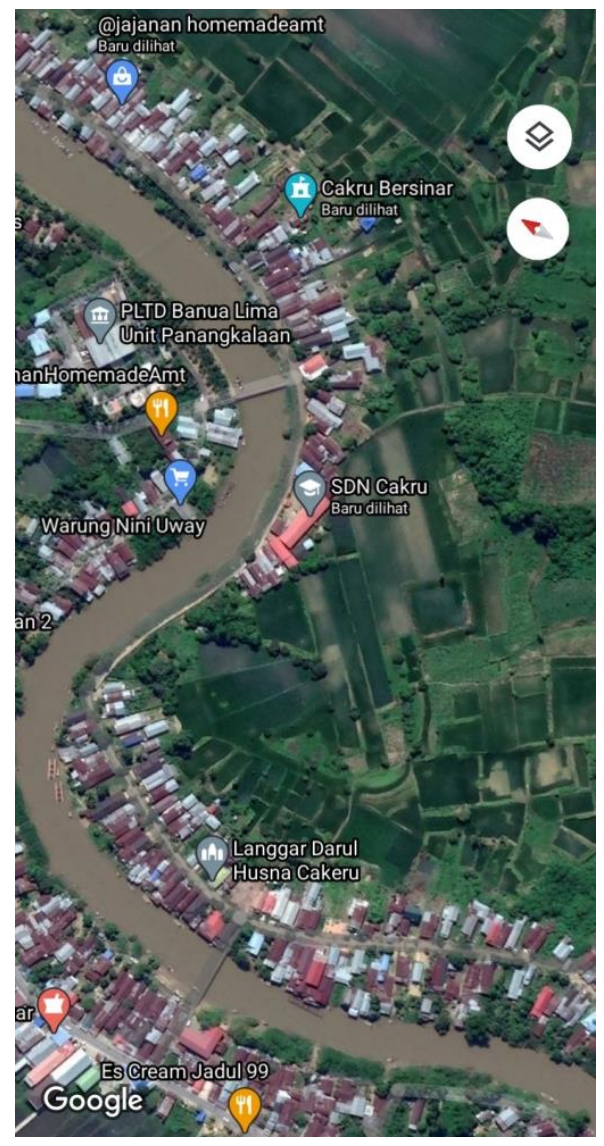

HASIL DAN PEMBAHASAN

KONSEP NILAI-NILAI KEAGAMAAN

46

Al-Khidma: Jurnal Pengabdian Masyarakat Vol 1 No 1 September 2021-Maret 2022 
Nilai-nilai keagamaan sangat identik dengan akhlak. Konsep lain yang setara namun berbeda dengan akhlak adalah moral dan etika. moral berasal dari bahasa Latin yaitu mos, artinya adat atau cara hidup. Sedangkan Etika berasal dari bahasa Yunani yaitu ethos yang artinya adat, watak atau kesusilaan. Perbedaannya terletak pada sumbernya. Akhlak bersumber pada al-Quran, etika bersumber pada pertimbangan rasio, dan moral bersumber pada adat kebiasaan yang berlaku dalam suatu masyarakat. Istilah tersebut sama-sama menentukan nilai baik dan buruk dari sikap atau perbuatan. Akhlak dapat dipahami sebagai sifat yang tertanam dalam jiwa manusia sehingga akan muncul secara spontan saat diperlukan tanpa memerlukan pemikiran atau pertimbangan terlebih dahulu. ${ }^{3}$

Pengoptimalan Nilai-nilai keagamaan yang dimaksud dalam tulisan ini adalah nilai dari aspek-aspek pendidikan agama Islam, antara lain nilai keimanan, ibadah, dan akhlak. Ketiga nilai tersebut dihubungkan dengan cakupan pendidikan agama Islam yang meliputi keserasian, keselarasan, dan keseimbangan antara hubungan manusia dengan Allah, diri sendiri, sesama manusia, dan lingkungan. Hubunganhubungan itu tergambar dalam bentuk sikap dan perilaku, berikut ini penjelasan masing-masing hubungan tersebut: ${ }^{4}$

\section{Sikap dan perilaku terhadap Allah}

Yang harus diajarkan kepada anak yang pertama dalam bersikap dan berperilaku kepada Allah adalah mentauhidkan Allah, yaitu mengakui bahwa tidak ada tuhan melainkan Allah. Meyakini atas keesaan Allah seperti bahwa perbuatan Allah tidak sama dengan perbuatan manusia, meskipun penamaannya sama.

${ }^{3}$ Muhammad Azmi, Pembinaan Akblak. Anak Usia Pra-Sekolab: Upaya Mengefektiffean Nilai-nilai Pendidikan Islam dalam Keluarga (Yogyakarta: Belukar, 2006), h. 55-56.

${ }^{4}$ Muhammad Azmi, h. 63-78. 
Bentuk sikap dan perilaku yang harus ditanamkan antara lain: mencintai Allah melebihi cinta kepada yang lain, melaksanakan perintahnya dan menjauhi larangannya, mengharap dan berusaha mencapai ridha Allah, mensyukuri segala pemberian dan karunia Allah, ikhlas dan tabah menerima musibah.

\section{Sikap dan perilaku terhadap sesama manusia}

Hubungan sesama manusia dapat dibina dan dipelihara dengan sikap saling tolong menolong, saling memaafkan, menepati janji, lapang dada, menegakkan keadilan baik bagi diri sendiri maupun bagi orang lain. ${ }^{5}$ Sikap dan perilaku terhadap sesama manusia dapat dikelompokkan dalam beberapa bagian.

Pertama, kepada Rasulullah, sikap dan perilaku kepada rasulullah diwujudkan dalam bentuk menjadikan Rasulullah sebagai idola dan teladan kehidupan, melaksanakan segala perintah dan menjauhi larangannya dan mengikuti sunnah-sunnahnya.

Kedua, kepada orang tua. Sikap dan perilaku kepada orang tua diwujudkan dengan menghormati, menaati, berbuat baik dan lemah lembut kepada beliau.

Ketiga, kepada keluarga. Sikap dan perilaku kepada keluarga diwujudkan dengan saling membina rasa kasih sayang, memelihara silaturahmi, menunaikan hak dan kewajiban.

Keempat, kepada tetangga. Sikap dan perilaku kepada tetangga diwujudkan dengan saling mengunjungi, membantu, memberi, menghormati, dan menghindari pertengkaran.

Kelima, kepada masyarakat. Sikap dan perilaku kepada masyarakat diwujudkan dengan memuliakan tamu, menghormati nilai dan norma yang berlaku, saling

${ }^{5}$ Mohammad Daud Ali, Pendidikan Agama Islam (Jakarta: PT. RajaGrafindo Persada, 2010), h. 106. 
tolong menolong dan mengingatkan dalam kebaikan dan mencegah perbuatan buruk. $^{6}$

\section{Sikap dan perilaku terhadap lingkungan}

Hormat kepada lingkungan merupakan suatu prinsip dasar bagi manusia sebagai bagian dari alam semesta. ${ }^{7}$ Sikap dan perilaku manusia terhadap lingkungan sekitar dapat diwujudkan dengan cara memelihara dan menyayangi binatang, tumbuhan, dan semua hal yang Allah ciptakan di dunia ini dan mencegah perusakannya. ${ }^{8}$

Islam memandang alam sebagai milik Allah yang wajib disyukuri dengan menggunakan dan mengelola lingkungan sebaik-baiknya, agar dapat memberi manfaat bagi kehidupan manusia. Untuk itu, sikap dan perilaku kepada lingkungan perlu ditanamkan kepada anak sedini mungkin, agar mereka dapat memelihara kebersihan dan keindahan lingkungan, serta memelihara dan menjaga keseimbangan alam, sehingga tetap nyaman dan indah sebagai wujud ketaatan kepada Allah.

Nilai-nilai tersebut dapat ditanamkan pada anak sejak kecil agar mereka memahami nilai-nilai islami secara konkret dan terbiasa untuk mempraktekkannya dalam kehidupan. ${ }^{9}$

\section{OPTIMALISASI NILAI-NILAI KEAGAMAAN PADA BELAJAR MALAM}

\footnotetext{
${ }^{6}$ Muhammad Azmi, h. 64-77.

7 A. Sonny Keraf, Etika Lingkungan Hidup (Jakarta: Penerbit Buku Kompas, 2010), h. 167.

8 Mohammad Dand Ali, h. 371.

9 Maksudin, Pendidikan Nilai Komprehensif: Teori dan Praktik (Jakarta: UNY Press, 2009), h. 114.
} 
Hal yang paling berpengaruh terhadap pendidikan islam terutama dalam segi akhlak pada saat ini adalah Globalisasi. Globalisasi mempunyai dampak atau pengaruh yang sangat besar bagi kehidupan umat manusia terutama pada kalangan pelajar dari berbagai aspek kehidupan. Globalisasi telah banyak mempengaruhi generasi muda islam, Saat ini pengaruh pergaulan bebas pada remaja seakan tidak mengenal tatakrama, semakin terkikisnya nilai-nilai keimanan adalah salah satu penyebab dari globalisasi.

Di era globalisasi ini, munculnya alat-alat canggih juga sangat berpengaruh terhadap perubahan akhlak pada generasi muda islam. Pada saat ini perilaku mereka justru banyak terfokus terhadap handphonenya di bandingkan peduli dengan keaadaan di sekitarnya. Ketika mereka berinteraksi dengan handphonenya tanpa mereka sadari mereka telah mengurangi sosialisasi dengan lingkungan yang ada di sekitarnya.

Dari sinilah otak manusia khususnya generasi muda islam di desain dengan sedemikian rupa oleh bangsa barat dengan tujuan sedikit demi sedikit untuk merusak atau menghancurkan generasi islam dengan cara memunculkan alat-alat elektronik yang canggih. Inilah yang di sebut dengan penjajahan akhlak terutama di zaman modern ini.

Belajar malam adalah sebuah program yang didalamnya terdapat serangkaian kegiatan yang berupa proses pembelajaran pendidik terhadap yang di didik dengan harapan setelah dilaksanakannya bimbingan tersebut dapat meningkatkan hasil belajar dari peserta diidik selain upaya guru dalam meningkatkan hasil belajar siswa, di sisi lain guru juga memberikan bimbingan secara karakter melalui ketertiban siswa yang datang pada kegiatan belajar malam tersebut. ${ }^{1}$

1 Ali Hakim, “Program 'Belają Malam’ Studi Kasus Di MTS Muhammadiyah Al-Manar Desa Kenduren Kecamatan Wedung Kabupaten Demak Tahun 2018,” 2019. 


\section{Perencanaan dan persiapan Kegiatan}

Perencanaan menjadi aspek paling penting karena segala ide atau konsep untuk mencapai tujuan tertuang dalam perencanaan. Juga menjadi paling dasar karena melalui perencanaan, segala hal yang akan dilakukan bisa diukur dan diprediksi secara baik dan akurat.Kami melakukan musyawarah untuk merencanakan kegiatan belajar malam di desa Cakru.

Persiapan itu penting. Persiapan sebaiknya dilakukan secara terinci dan benarbenar matang, agar pelaksanaan kegiatan berjalan tanpa hambatan. Apalagi bagi para Pandu yang hendak bertualang atau berkelana di alam terbuka. Persiapan menjadi semakin penting untuk menghindari risiko yang mungkin terjadi.

Sebagai persiapan kegiatan belajar malam di desa Cakru, kami sebagai mahasiswa KKN melakukan observasi lingkungan di desa tersebut untuk mengetahui bagaimana keadaan anak-anak di desa Cakru sekaligus perkenalan kepada masyarakat bahwa kami mahasiswa KKN Sekolah Tinggi Ilmu Alquran Amuntai dan ingin mengadakan pembelajaran di malam hari. Respon dari masyarakata sangat baik dan mereka sangat antusias menyambut kehadiran kami dan mendukung kami untuk mengajarkan anak-anak mereka pelajaran agama di malam hari. Selain itu kami juga melakukan pendekatan kepada anak-anak agar mereka mau dan ingin belajar agama dengan kami.

Pembelajaran di laksanakan setelah sholat maghrib. Sebelum sholat maghrib, kami para mahasiswa KKN berdiskusi dan berbagi tugas untuk mengisi langar-langgar yang ada di desa Cakru. Jumlah langgar yang ada di desa Cakru ada empat buah. Namun ada satu buah langgar yang sedang di perbaiki. Sehingga langgar yang masih aktif tersisa tiga buah. Satu buah di RT 02, satu buah di RT 03 dan satu buahnya lagi di RT 04. Ada dua orang yang bertugas di setiap langgar tersebut. Siapa yang bertugas di langgar itu maka dia akan membawa anak-anak menuju tempat pembelajaran yaitu posko KKN. Hal itu di lakukan karena jalan menuju posko tersebut di kenal angker. 
Hal itu lah yang membuat sebagian anak-anak takut melalui jalan tersebut apalgi tidak ada pengawasan dari anggota KKN. Para orang tua juga merasa was-was apabila anaknya tidak di awasi dan di bimbing menuju posko KKN. Setelah pembelajaran berakhir kamipun melakukan hal yang sama, yaitu mengantar anak-anak pulang ke rumahnya.

pendidikan agama islam sangat penting bagi generasi islam untuk mewujudkan cita-cita masyarakat islam yang sesuai dengan perintah Allah swt. dan menanamkan Akhlakul Karimah sebagai bekal masa depannya kelak.

\section{Pelaksanaan Kegiatan}

Dalam pelaksanaan pembelajaran malam, kami mahasiswa KKN memberikan motivasi kepada anak-anak betapa pentingnya mempelajari agama islam. Di samping itu kami juga memberikan wawasan nilai-nilai kegamaan kepada mereka agar nantinya mereka bisa menjadi generasi islam yang memiliki wawasan yang luas dan akhlak yang baik.

Setelah memberikan motivasi dan memberikan wawasan kepada mereka, kami mengajarkan Tahsin agar bacaan mereka menjadi lebih baik dan benar. Karena membaca Alquran tidak hanya harus lancar saja. Akan tetapi harus dengan bacaan yang bagus dan benar. Di samping itu kami juga menanamkan agar selalu belajar dan membaca Alquran. Karena Alquran adalah kitab suci ummat islam dan menjadi pedoman bagi kehidupan manusia.

Kami juga melaksanakan pelatihan adzan kepada anak-anak desa Cakru agar nanti mereka bisa dan terbiasa untuk adzan di mesjid atau langgar. Kalau tidak di biasakan maka anak-anak akan malu untuk adzan di mesjid.

Kami juga melaksanakan sholat berjamaah kepada anak-anak. Agar mereka tahu betapa pentingnya sholat berjamaah dan mereka juga terbiasa melakukan sholat berjamaah. Dalam sholat berjamaah kami mengajarkan kepada mereka bagaimana 
menjadi imam dan menjadi makmum yang benar dan baik. Kami berusaha menanamkan agar mereka menyembah Allah dan mentaatinya dengan baik dan benar.

Kami juga mengajarkan nahwu dan sharaf ke salah satu anak yang ingin belajar dan mendalami masalah nahwu dan sharaf.

Terlepas dari semua itu kami berusaha memberikan contoh akhlak yang baik kepada orang yang lebih tua, sesama teman dan lingkungan. Kalau mereka melakukan hal yang tidak baik selama proses pembelajaran, maka kami akan menegur mereka dan menasehatinya.

Dengan adanya pembelajaran malam setidakmya dapat mengurangi anak-anak untuk memainkan game online di handphone mereka. Kami berharap semoga dengan adanya pembelajaran di malam hari ini dapat menbuat anak-anak desa Cakru selalu istiqamah dalam menuntut ilmu dan giat dalam belajar agar menjadi generasi penerus bangsa yang berpengetahuan luas dan berguna bagi bangsa, negara dan khususnya orang di sekitarnya.kami juga berharap dengan adanya malam bisa membuat anak-anak siap dan mampu untuk menahan gempuran-gempuran dari kaum kafir yang berusaha merusak generasi islam dengan cara merusak mental dan pola pikir mereka.

\section{PERAN MAHASISWA KKN PADA SAAT BELAJAR MALAM}

Di era pandemi saat ini, pembelajaran berubah drastis. Dulunya belajar dengan tatap muka, kini menjadi jauh dan membutuhkan jaringan untuk mendukungnya. Pembelajaran online ini membuat sebagian anak-anak sulit untuk memahami apa yang di jelaskan oleh guru. Pelajaran yang awalnya mudan di pahami menjadi sulit untuk di pelajari. Sebagian mungkin masih bisa bertanya dan belajar dengan orang tuanya. Namun sangat banyak orang tua yang pendidikannya hanya lulusan SD saja. hal ini tentu menjadikan beliau kurang bisa membantu pembelajaran anak beliau. Untuk itulah kami mahasiswa KKN mengajarkan mereka pelajaran sekolah yang sulit mereka pahami agar mereka bisa memahaminya dengan mudah. 
Pelajaran nahwu dan sharaf merupakan pelajaran yang harus di pelajari bagi mereka yang sekolah di pondok pesantren. Salah satu anak di desa Cakru ada yang sekolah di pondok pesantren dan dia ingin belajar nahwu dan sharaf. Kamipun mengajarkan dia nahwu dan sharaf agar dia bisa memahami kaidah-kaidah nahwu dan sharaf.

Membaca Alquran dapat menentramkan hati. Salah satu manfaat yang akan dirasakan bagi orang yang rajin membaca Alquran adalah hati terasa lebih damai dan nyaman. Membaca Alquran berarti mengingat-ingat akan kebesaran Allah SWT. Membaca Alquran sebaiknya di mulai dejak dini. Kami mahasiswa KKN mengajarkan anak-anak desa Cakru untuk belajar membaca Alquran dan mengajarkan tajwid dan tahsin kepada mereka. Karena membaca Alquran harus tahu tajwid dan benar penyebutan hurufnya. Manfaat lain Tahsin adalah dapat merangsang hati untuk melakukan tadabbur (perenungan) ayat yang sedang dibaca. Hanya dengan tilawah yang baik dan suara yang baguslah, lantunan suara ayat-ayat Alquran menjadi indah, meresap dan menggerakkan pikiran si pembacanya.

Keutamaan menghafal Alquran bagi umat Islam. Selain membaca, seorang muslim akan lebih baik jika menghafal dan mempelajari isi kandungan Alquran. Alquran memberi petunjuk jalan yang lurus dan memberi bimbingan kepada umat manusia dalam menempuh perjalanan hidupnya. Tentunya petunjuk agar selamat di dunia dan akhirat. Sebagian anak-anak desa Cakru ada yang sedang menghafal Alquran. Kami mahasiswa KKN membantu mereka dalam menghafal dengan melakukan sambung ayat dan menyuruh mereka membacakan surah-surah pendek yang telah mereka hafal. Agar hafalan mereka menjadi lebih kuat dan lebih mantap.

Shalat memberikan banyak manfaat bagi yang istiqamah menjalankannya. Selain itu, shalat memiliki banyak keutamaan, apalagi jika ditunaikan berjamaah. Satu hal yang perlu diketahui, tidak satu pun ulama yang menyatakan shalat berjamaah hukumnya sunah biasa. 
Shalat berjamaah adalah sunah muakkadah bagi laki-laki dalam menjalankan shalat lima waktu. Menurut Mazhab Maliki dan Hambali, hukumnya wajib.

Kami mahasiswa KKN mengajarkan dan membiasakan anak-anak desa Cakru untuk sholat berjamaah. Setelah masuk waktu isya, kami menyuruh mereka untuk adzan sekaligus mengajarkan mereka bagaimana adzan yang bagus dan benar dan bagaimana adab ketika mendengar orang adzan. Setelah adzan qamat, kami membimbing mereka untuk sholat berjamaah sekaligus mengajarkan mereka bagaimana jadi imam dan jadi makmum yang baik dan benar. Kami juga mengajarkan bagaimana berwirid setelah sholat dan membaca doa.

Begitu pentingnya akhlak bagi setiap umat muslim dalam membentengi kaidahnya dalam Islam. Karena jika seorang muslim membentengi dirinya dengan akhlak yang mulia maka sama saja ia menjaga dan membentengi akidahnya dari hal-hal buruk yang masuk kepada dirinya.

Kami mahasiswa KKN menanamkan adab kepada anak-anak desa Cakru dengan memberikan contoh dan teguran ketika mereka berbuat salah. Misalnya ketika mereka minum dengan berdiri, maka kami suruh untuk duduk. Karena minum berdiri itu tidak baik.

\section{SIMPULAN}

Pengoptimalan nilai-nilai kegamaan dapat di lakukan dengan cara belajar malam. Pelaksanaan kegiatan ini meliputi pemberian motivasi kepada anak-anak, penambahan dan penanaman nilai-nilai keagamaan, mengajarkan mereka membaca Alquran dan memperbaiki bacaannya, melatih adzan sekaligus membiasakan mereka untuk sholat berjamaah.

Dengan adanya pembelajaran malam setidaknya dapat mengurangi anak-anak untuk memainkan game online di handphone mereka. Dengan kegiatan tersebut kami 
juga berharap agar anak-anak desa Cakru dapat memiliki akhlak dan adab yang bagus baik kepada sesama, orang tau maupun kepada Allah dan Rasulnya.

\section{DAFTAR PUSTAKA}

A. Sonny Keraf. Etika Lingkungan Hidup. Jakarta: Penerbit Buku Kompas, 2010.

Ali Hakim. “Program ‘Belajar Malam’ Studi Kasus Di MTS Muhammadiyah Al-Manar Desa Kenduren Kecamatan Wedung Kabupaten Demak Tahun 2018,” 2019.

Lexy J. Moelong. Metodologi Penelitian Kualitatif. Bandung: PT. Remaja Rosdakarya, 2006.

Maksudin. Pendidikan Nilai Komprehensif: Teori dan Praktik. Jakarta: UNY Press, 2009.

Mohammad Daud Ali. Pendidikan Agama Islam. Jakarta: PT. RajaGrafindo Persada, 2010.

Muhammad Azmi. Pembinaan Akblak Anak Usia Pra-Sekolab: Upaya Mengefektifkan Nilai-nilai Pendidikan Islam dalam Keluarga. Yogyakarta: Belukar, 2006.

Nana Syaodih Sukmadinata. Metode Penelitian Pendidikan. Bandung: PT. Remaja Rosdakarya, 2010. 